Eur. J. Clin. Chem. Clin. Biochem.

Vol. 31, 1993, pp. 323-327

(C) 1993 Walter de Gruyter \& Co. Berlin - New York

\title{
Falsely Low Results in CA 125 Determination Due to Anti-Idiotypic Antibodies Induced by Infusion of $\left[{ }^{131} \mathrm{I}\right] \mathrm{F}\left(\mathrm{ab}^{\prime}\right)_{2}$ Fragments of the OC125 Antibody
}

\author{
By J. Reinsberg and W. Nocke \\ Zentrum für Frauenheilkunde und Geburtshilfe, Universität Bonn, Bonn, Germany
}

(Received November 24, 1992/February 16, 1993)

\begin{abstract}
Summary: We investigated a one-step immunometric CA 125 assay, which employs new anti-CA 125 antibodies as capture antibodies and OC125 antibodies for detection, for interference due to antibodies induced by repeated administration of $\mathrm{F}\left(\mathrm{ab}^{\prime}\right)_{2}$ fragments of the anti-CA 125 antibody OC125. Testing 33 samples, obtained from 13 patients treated with OC125 fragments, we found falsely high CA 125 concentrations only in samples with exceptionally high concentrations of both anti-idiotypic antibodies and non-specific human anti-mouse antibodies. In contrast, the recovery of added CA 125 was already diminished in the presence of low antiidiotypic antibody concentrations. Both interferences disappeared after removal of serum IgG. It was possible to eliminate the falsely high results, but not the reduction in recovery rate, by adding non-specific murine IgG. When the binding of the detector antibodies was performed in a separate incubation step, no reduction in recovery rate was observed. Our results suggest that non-specific human anti-mouse antibodies are responsible for falsely high results. The reduction in the recovery rate is obviously due to an inhibition of the binding of OC125 detector antibodies by anti-idiotypic antibodies. In patients receiving OC125 antibodies CA 125 can be measured using OC125 detector antibodies if a two-step assay is performed. An increase in CA 125 following OC125 infusion should be confirmed after the addition of non-specific murine IgG.
\end{abstract}

\section{Introduction}

For the last couple of years the murine monoclonal antibody OC125, initially developed by Bast et al. (1, 2) to measure immunometrically the concentration of CA 125 in the serum of ovarian cancer patients, has also been used in vivo for radioimmunodetection of CA $125(3,4)$. Recently we demonstrated that in vivo application of $\mathrm{F}\left(\mathrm{ab}^{\prime}\right)_{2}$ fragments of the $\mathrm{OC} 125$ antibody is useful for therapy of ovarian cancer as well, leading to a significant prolongation of the survival rate of patients $(5-7)$.

One effect of in vivo application of $\mathrm{OC} 125 \mathrm{~F}\left(\mathrm{ab}^{\prime}\right)_{2}$ fragments is the induction of antibody formation (8). In a previous investigation we demonstrated that among the antibodies directed against epitopes common to all murine antibodies, anti-idiotypic antibodies directed against the hypervariable region of the applied $\mathrm{F}\left(a b^{\prime}\right)_{2}$ fragments are formed as well (9). These anti-idiotypic antibodies interfere with the determination of CA 125 when a homologous immunometric assay with $\mathrm{OC} 125$ antibodies as both the immobilized and the labelled antibody is used. In an assay of this kind, anti-idiotypic antibodies can crosslink both antibodies, resulting in falsely high values for CA $125(9,10)$. Obviously, the occurrence of falsely high values can be eliminated using other antiCA 125 antibodies on the solid phase $(9,11,12)$. However, in two test kits involving various anti-CA 125 capture antibodies we observed falsely low results in samples with elevated concentrations of anti-idiotypic antibodies $(11,12)$. Our results suggested that depending on the test protocol, anti-idiotypic antibodies can reduce the assay response resulting in falsely low values for CA 125 , especially when OC125 antibodies are used for detection. 
In the present study we investigated an immunometric test for CA 125 that involves a newly developed antiCA 125 antibody on the solid phase and ${ }^{125}$ I-labelled OC125 antibodies for detection, for interferences due to antibodies formed after treatment with OC125 fragments. Furthermore, the mechanisms of the observed interferences were investigated.

\section{Materials and Methods}

Patients and serum samples

All serum samples investigated were obtained routinely during follow-up of ovarian cancer patients (Stage II - IV FIGO). The samples were aliquoted and stored at $-20^{\circ} \mathrm{C}$ until analysis. Thirty and three samples were drawn from 13 patients who had received one or more infusions of $1 \mathrm{mg}{ }^{131}$ I-labelled $\mathrm{F}\left(\mathrm{ab}^{\prime}\right)_{2}$ fragments of the anti-CA 125 antibody OC125 (IMACIS-2; Isotopen Diagnostik CIS, Dreieich, Germany) for radioimmunodetection. Two control samples were obtained from two other ovarian cancer patients not yet treated with OC125 antibodies.

\section{Determination of CA 125}

CA 125 was measured with the ELSA-CA 125 II (Isotopen Diagnostik CIS, Dreieich, Germany), a solid-phase immunometric assay employing a newly developed murine monoclonal anti-CA 125 antibody as capture antibody. OC125 antibodies serve only as ${ }^{125}$ I-labelled detector antibodies. According to the normal test protocol proposed by the manufacturers, the binding of both antibodies takes place simultaneously during one incubation step: $0.1 \mathrm{ml}$ of the samples were incubated together with $0.3 \mathrm{ml}$ of radioiodinated OC125 antibodies in test tubes coated with anti-CA 125 capture antibodies $(20 \mathrm{~h}$, room temperature). After the incubation the tubes were washed and the bound radioactivity was measured.

In some cases we performed a modified two-step test in order to exclude the possibility that serum components not bound to the solid phase might interfere with the binding of detector antibodies: in the first step $0.1 \mathrm{ml}$ of sample were incubated $(20 \mathrm{~h}$, room temperature) with the immobilized capture antibodies together with $0.3 \mathrm{ml}$ of zero standard (provided with the ELSA-CA 125 II test kit) supplemented with $0.1 \mathrm{~g} / 1$ of nonspecific murine IgG (Calbiochem Novabiochem, Bad Soden, Germany). After the incubation the tubes were washed to remove all serum components not bound to the solid phase. In the second step $0.3 \mathrm{ml}$ of radioiodinated OC125 antibodies were incubated $(20 \mathrm{~h}$, room temperature) with $0.1 \mathrm{ml}$ of zero standard. After a further wash the bound radioactivity was measured. If not otherwise indicated the test was performed according to the normal test protocol.

\section{Recovery of CA 125}

In order to identify inhibitory agents in serum samples we determined the recovery of a known amount of CA 125 added to the native serum: $0.01 \mathrm{ml}$ of a serum pool from an ovarian cancer patient with a CA 125 concentration of $5000 \times 10^{3}$ arb. $\mathrm{U} / \mathrm{l}$ were added to $0.24 \mathrm{ml}$ of sample and the resulting CA 125 concentration was measured with the ELSA-CA 125 II. Recovery was expressed as fraction of the amount added.

\section{Determination of anti-idiotypic antibodies}

Anti-idiotypic antibodies were determined with the Abbott CA 125 EIA monoclonal. Since in this immunometric test the
OC125 antibodies are used as both the immobilized and the labelled antibodies, anti-idiotypic antibodies directed against idiotypes of the OC125 can simulate the presence of antigen by cross-linking capture and detector antibodies $(9,10)$. Thus, in samples with low CA 125 concentrations the results of the CA 125 EIA almost exclusively reflect theieffect of the anti-idiotypic antibodies. The test was performed according to the manufacturers' instructions. The concentration of anti-idiotypic antibodies was expressed, as is CA 125 , in arb. U/l.

Determination of non-specific human anti-mouse antibodies

Non-specific anti-mouse antibodies (anti-iso/allotypic antibodies) were determined with the ImmuSTRIP HAMA-EIA (Immunomedics Inc., Newark, NJ) as previously described (9).

\section{Removal of interfering IgG from serum samples}

Interfering IgG were removed by affinity chromatography on Protein G-Sepharose (Pharmacia, Freiburg, Germany). We applied $1 \mathrm{ml}$ of serum sample diluted 2-fold with phosphate buffer ( 0.2 mol sodium phosphate and $10 \mathrm{~g}$ bovine serum albumin per litre, $\mathrm{pH} 7.0$ ) to the $2,5 \mathrm{ml}$ column equilibrated with phosphate buffer. After a 5-min incubation at room temperature, the column was washed with $8 \mathrm{ml}$ of phosphate buffer to elute the unadsorbed fraction. The complete wash fraction was frozen immediately at $-80^{\circ} \mathrm{C}$ and subsequently lyophilized. At the time of further use the IgG-free samples were reconstituted with $1 \mathrm{ml}$ of distilled water. The absorbed $\mathrm{IgG}$ fraction was eluted with $4 \mathrm{ml}$ of elution buffer ( $1 \mathrm{~mol} / 1$ glycine $\mathrm{HCl}$ buffer, $\mathrm{pH} 2.8$ ), after a further wash with $5 \mathrm{ml}$ of phosphate buffer. The eluate was neutralized immediately with $0.4 \mathrm{ml}$ of neutralizing buffer ( $1 \mathrm{~mol} / 1$ sodium phosphate, $\mathrm{pH} 8.0$ ), frozen at $-80^{\circ} \mathrm{C}$ and lyophilized. At the time of further use the IgG fractions were reconstituted with $1 \mathrm{ml}$ of distilled water.

Blocking of non-specific human anti-mouse antibodies

To block anti-iso/allotypic antibodies non-specific murine IgG (Calbiochem Novabiochem, Bad Soden, Germany) were added to the native serum samples. Murine $\mathrm{IgG}$ solution $(0.01 \mathrm{ml})$ $(16.6 \mathrm{~g} / \mathrm{l})$ was added to $0.24 \mathrm{ml}$ of sample.

\section{Results}

\section{Falsely high CA 125 values}

In 33 serum samples, obtained from 13 patients after treatment with OC125 fragments, we determined the apparent CA 125 concentration with the ELSA-CA $125 \mathrm{II}$. While the real CA 125 concentrations determined after removal of interfering IgG in all samples were lower than $30 \times 10^{3}$ arb. $U / 1$, in 7 native samples, with elevated concentrations of both anti-idiotypic antibodies $\left(8400-1552000 \times 10^{3} \mathrm{arb} . \mathrm{U} / \mathrm{l}\right)$ and non-specific human anti-mouse antibodies (965$18800 \mu \mathrm{g} / \mathrm{l})$, we measured falsely high CA 125 values up to $126 \times 10^{3}$ arb. U/l. It was possible to reduce 
the falsely high $\mathrm{Ca} 125$ values by addition of nonspecific murine IgG. In 4 samples with falsely high results the apparent CA 125 concentrations were reduced to values lower than $10 \times 10^{3}$ arb. $U / 1$ after addition of $0.66 \mathrm{~g} / \mathrm{l}$ murine IgG. The CA 125 concentrations measured with the ELSA-CA 125 II in two control samples were not influenced by the addition of murine IgG (tab. 1).

Tab. 1. Effect of addition of non-specific murine IgG on falsely high CA 125 results measured with the ELSA-CA 125 II in 4 samples with elevated concentrations of antiidiotypic antibodies and non-specific human antimouse antibodies (HAMA), and on the CA 125 concentration of 2 controls.

\begin{tabular}{|c|c|c|c|c|}
\hline \multirow[t]{2}{*}{$\begin{array}{l}\text { Sample } \\
\text { no. }\end{array}$} & \multirow{2}{*}{$\begin{array}{l}\text { Anti-idiotypic } \\
\text { antibodies } \\
{\left[10^{3} \text { arb. } U / 1\right]}\end{array}$} & \multirow{2}{*}{$\begin{array}{l}\text { HAMA } \\
{[\mu \mathrm{g} / 1]}\end{array}$} & \multicolumn{2}{|c|}{$\begin{array}{l}\text { Apparent CA } 125 \\
{\left[10^{3} \text { arb. U/l }\right]}\end{array}$} \\
\hline & & & Native & + Murine Ig \\
\hline $3844^{*}$ & n.d.** & $<60$ & 328 & 318 \\
\hline $4177^{*}$ & n.d.** & $<60$ & 140 & 141 \\
\hline 1549 & 8442 & 965 & 74 & 6 \\
\hline 2203 & 196000 & 11000 & 38 & n. d. $* *$ \\
\hline 2835 & 416000 & 7600 & 89 & n.d.** \\
\hline 3621 & 1552000 & 18800 & 61 & 10 \\
\hline
\end{tabular}

* control samples

** not detected

\section{Falsely low CA 125 values}

Figure 1 shows the extent of recovery of added $\mathrm{Ca}$ 125 from 25 samples obtained from 13 patients using two different test protocols. When CA 125 was determined with the ELSA-CA 125 II according to the normal test protocol, the recovery of CA 125 was diminished in the presence of anti-idiotypic antibodies in a concentration-dependent manner. From samples

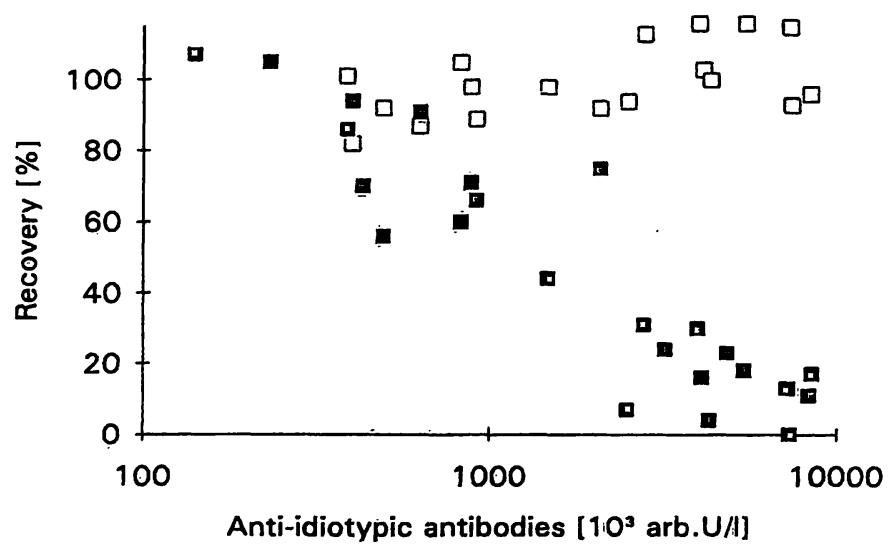

Fig. 1. Relationship between the concentration of anti-idiotypic antibodies and the extent of recovery of added CA 125 , measured with the ELSA-CA 125 II according to the normal one-step ( $\square$ ) and the modified two-step ( $\square$ ) test protocol, from 25 serum samples obtained from 13 patients after OC125 treatment. with anti-idiotypic antibody concentrations exceeding $5000 \times 10^{3}$ arb. U/1 less than $20 \%$ of the added CA 125 was recovered. When binding of the detector antibodies was performed in a separate incubation step according to the modified test protocol, the CA 125 recovery was quite good. Further, from samples with anti-idiotypic antibody concentrations exceeding $5000 \times 10^{3} \mathrm{arb}$. U/1 the CA 125 was recovered completely.

In 5 samples with reduced recovery rates we removed serum IgG by means of chromatography on protein $\mathrm{G}$ sepharose. After IgG removal, the added CA 125 was recovered nearly completely from all samples, whereas from the IgG-containing elution fraction of the protein $G$ column the recovery was diminished (fig. 2).

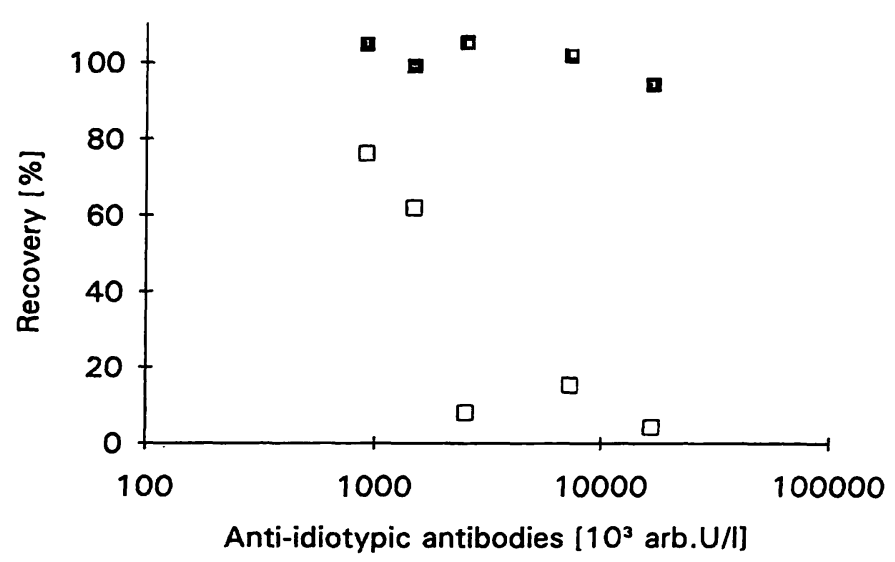

Fig. 2. Relationship between the concentration of anti-idiotypic antibodies and the extent of recovery of added CA 125 from 5 serum samples after IgG removal with protein $\mathrm{G}(\square)$ and from the IgG-containing eluate of the protein $\mathrm{G}$ column (口).

Non-specific murine IgG were added to another 5 samples with reduced recovery rates to block putative activity of non-specific human anti-mouse antibodies. The recovery rates were not influenced by the addition of $(0.66 \mathrm{~g} / \mathrm{l})$ murine IgG (tab. 2).

Tab. 2. Effect of addition of non-specific murine IgG on the reduced recovery rates measured with the ELSA-CA $125 \mathrm{II}$ in 5 samples with elevated concentrations of antiidiotypic antibodies.

\begin{tabular}{llll}
\hline $\begin{array}{lll}\text { Samples } \\
\text { no. }\end{array}$ & $\begin{array}{l}\text { Anti-idiotypic } \\
\text { antibodies } \\
{\left[10^{3} \text { arb. U/l] }\right.}\end{array}$ & \multicolumn{2}{l}{$\begin{array}{l}\text { \% Recovery } \\
\text { of added CA 125 }\end{array}$} \\
\cline { 3 - 4 } \cline { 3 - 4 } & & Native & + Murine Ig \\
\hline 5179 & 3225 & 24 & 23 \\
1717 & 4115 & 16 & 13 \\
2029 & 4843 & 23 & 27 \\
1602 & 7343 & 0 & 1 \\
3402 & 16627 & 5 & 0 \\
\hline
\end{tabular}




\section{Discussion}

The present results confirm that anti-idiotypic antibodies formed after repeated administration of $\mathrm{OC} 125$ fragments do not bind to the capture antibodies used in the ELSA-CA 125 II. Thus, falsely high values, as observed with a homologous assay involving OC125 antibodies as both the immobilized and the labelled antibodies (9), cannot occur in this test. Falsely high values were only observed in serum samples with very high concentrations of anti-idiotypic antibodies and non-specific human anti-mouse antibodies. Such interference was eliminated by IgG removal, indicating that the responsible agents were human serum IgG. In a previous study we observed similar effects with two other immunometric assays for CA 125 which also employ no OC125 antibodies on the solid phase (11). We assume that such interference may be due to non-specific human anti-mouse antibodies formed after treatment' with OC125 fragments, which simulate the presence of antigen by crosslinking capture and detector antibodies. Interference by non-specific human anti-mouse antibodies has been reported for several immunometric assays $(13-16)$. Thus, as with the ELSA-CA 125 II we used in this study, most immunoassays include non-specific murine immunoglobulins to block the activity of non-specific human antimouse antibodies $(14,15,17)$. However, as demonstrated by Boscato \& Stuart (18), in samples with very high concentrations of non-specific human antimouse antibodies the amount of murine immunoglobulin added to an assay system may not always be enough to prevent interference. Falsely high results in the ELSA-CA 125 II may be due to non-specific human anti-mouse antibodies not further blocked by murine immunoglobulins. This hypothesis is supported by the fact that it was possible to block interference by the addition of murine IgG.

\section{References}

1. Bast, R. C., Freeney, M., Lazarus, H., Nadler, L. M., Colvin, R. B. \& Knapp, R. C. (1981) Reactivity of monoclonal antibody with human ovarian carcinoma. J. Clin. Invest. 68, $1331-1337$.

2. Bast, R. C., Klug, T. L., St. John, E., Jenison, E., Niloff, J. M., Lazarus, H., Berkowitz, R. S., Leavitt, T., Griffiths, C. T., Parker, L., Zurawski, V. R. \& Knapp, R. C. (1983) A radioimmunoassay using a monoclonal antibody to monitor the course of epithelial ovarian cancer. N. Engl. J. Med. 309, 883-887.

3. Perkins, A. C., Powell, M. C., Pimm, M. V., Wastie, M. L., Symonds, E. M. \& Baldwin, R. W. (1986) Immunoscintigraphy of gynecological tumors. In: Nuclear Medicine in Clinical Oncology - Current Status and Future Aspects (Winkler, C., ed.) Springer, Berlin-Heidelberg-New York, pp. 177-186.
A more prominent interference observed with the ELSA-CA $125 \mathrm{II}$ is the reduction of assay response, which is evident in recovery studies. The negative correlation between the extent of recovery and the concentration of anti-idiotypic antibodies and the fact that the inhibitory agents were absorbed by protein $\mathrm{G}$ and were recovered in the IgG-containing eluate, suggest that the responsible agents were human serum IgG formed together with the anti-idiotypic antibodies after treatment with OC125 fragments. Reduction of assay response can be produced by high concentrations of non-specific human anti-mouse antibodies, presumably due to the inhibition of antigen-binding to reagent antibodies $(18,19)$. However, the effect observed with the ELSA-CA 125 II cannot be ascribed to non-specific human anti-mouse antibodies because it could not be blocked by murine IgG. The fact that no interference occurred in the modified two-step test version indicates that interfering agents react with the OC125 detector antibodies used in the test studied. Thus, the results support the hypothesis that the reduction of assay response is due to anti-idiotypic antibodies that mask the OC125 detector antibodies and prevent the binding of CA 125. This is also in accordance with the fact that we observed no reduction of assay results in the presence of anti-idiotypic antibodies with another two-step immunometric CA 125 assay using OC125 antibodies for detection (12).

The use of test kits involving no OC125 antibodies as capture antibodies cannot completely eliminate interference by antibodies newly formed after the treatment with OC125 fragments. Even with these tests falsely high results can occur, due presumably to high concentrations of non-specific human anti-mouse antibodies. Thus, increased CA 125 values following OC125 application should be confirmed after addition of non-specific murine IgG. To avoid falsely low results, assays involving $\mathrm{OC} 125$ antibodies for detection should be performed in a two-step protocol.

4. Brökelmann, J., Bockisch, A., Vogel, J., Reinsberg, J., Oehr, P., Biersack, H. J. \& Krebs, D. (1989) Immunoscintigraphy using CA 125 antibodies in the management of ovarian cancer. Arch. Gynecol. Obstet. 244, 193-206.

5. Wagner, U., Reinsberg, J., Oehr, P., Briele, B., Schmidt, S., Werner, A., Krebs, D. \& Biersack, H. J. (1990) Clinical courses of patients with ovarian carcinomas after induction of anti-idiotypic antibodies against a tumour associated antigen. Tumordiagn. Ther. $11,1-4$.

6. Wagner, U., Reinsberg, J. \& Krebs, D. (1990) Versuch einer Immuntherapie des Ovarialkarzinomes durch IdiotypenVakzination. Geburtsh. u. Frauenbeilk. 50, 785-788.

7. Wagner, U., Oehr, P., Reinsberg, J.; Schmidt, S., Schlebusch, H., Werner, A. \& Krebs, D. (1992) Immunotherapy of advanced ovarian carcinomas by the activation of the idiotypic network. Biotech. Therapeutics 3, 81-89. 
8. Muto, M. G., Lepisto, E. M., Van den Abbeele, A. D., Knapp, R. C. \& Kassis, A. I. (1989) Influence of human antimurine antibody on CA 125 levels in patients with ovarian cancer undergoing radioimmunotherapy or immunoscintigraphy with murine monoclonal antibody $\mathrm{OC}$ 125. Am. J. Obstet. Gynecol. 161, 1206-1212.

9. Reinsberg, J., Heydweiller, A., Wagner, U., Pfeil, K., Oehr, P. \& Krebs, D. (1990) Evidence for interaction of human anti-idiotypic antibodies with CA 125 determination in a patient after radioimmunodetection. Clin. Chem. 36, 164167.

10. Klug, T. L., Green, P. J., Zurawski, V. R. \& Davis, H. M. (1988) Confirmation of a false positive result in CA 125 immunoradiometric assay caused by human anti-idiotypic immunoglobulin. Clin. Chem. 34, 1071-1076.

11. Reinsberg, J., Schultes, B., Wagner, U. \& Krebs, D. (1993) Monitoring of CA 125 in serum of ovarian cancer patients after administration of ${ }^{131} \mathrm{I}-\mathrm{F}\left(\mathrm{ab}^{\prime}\right)_{2}$ fragments of the $\mathrm{OC} 125$ antibody. Clin. Chem. (in press).

12. Reinsberg, J., Wagner, U., Volkmuth, S. \& Krebs, D. (1993) Antikörper-Induktion durch Gabe von OC125-Fragmenten und ihre Bedeutung für den Nachweis von CA 125. Arch. Gynecol. Obstet. (in press).

13. Howanitz, P. J., Howanitz, J. H., Lamberson, H. V. \& Ennis, K. M. (1982) Incidence and mechanism of spurious increases in serum thyrotropin. Clin. Chem. 28, 427-431.
14. Thompson, R. J., Jackson, A. P. \& Langlois, N. (1986) Circulating antibodies to mouse monoclonal immunoglobulins in normal subjects - incidence, species specificity, and effects on a two-site assay for creatinine kinase-MB isoenzyme. Clin. Chem. 32, 476-481.

15. Boscato, L. M. \& Stuart, M. C. (1986) Incidence and specificity of interference in two-site immunoassays. Clin. Chem. 32, 1491-1495.

16. Primus, F. J., Kelly, E. A., Hansen, H. J. \& Goldenberg, D. M. (1988) "Sandwich"-type immunoassay of carcinoembryonic antigen in patients receiving murine monoclonal antibodies for diagnosis and therapy. Clin. Chem. 34, 261 264.

17. Klug, T. L., Bast, R. C., Niloff, J. M., Knapp, R. C. \& Zurawski, V. R. (1984) Monoclonal antibody immunoradiometric assay for an antigenic determinant (CA 125) associated with human epithelial ovarian cancer. Cancer Res. 44, 1048-1053.

18. Boscato, L. M. \& Stuart, M. C. (1988) Heterophilic antibodies: a problem for all immunoassays. Clin. Chem. 34, 27-33.

19. Zweig, M. H., Csako, G., Benson, C. C., Weintraub, B. D. \& Kahn, B. B. (1987) Interference by anti-immunoglobulin $\mathrm{G}$ antibodies in immunoradiometric assays for thyrotropin involving mouse monoclonal antibodies. Clin. Chem. 33, $840-844$.

Dr. J. Reinsberg

Zentrum für Frauenheilkunde und Geburtshilfe Universität Bonn

Sigmund-Freud-Straße 25

W-5300 Bonn 1

Bundesrepublik Deutschland 


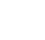

